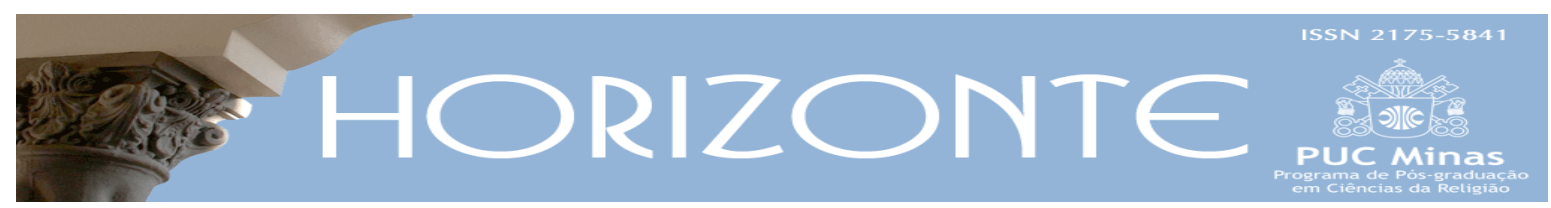

Temática Livre - Artigo Original

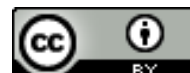

DOI - 10.5752/P.2175-5841.2016v14n44p1589

\title{
As memórias da capelania militar e o Serviço de Assistência Religiosa do Exército Brasileiro: história, (in)tolerância e chefia castrense
}

\author{
The memories of the military chaplaincy and Religious Assistance \\ Service of the Brazilian Army: history, (in)tolerance and castrense leadership
}

\begin{abstract}
Leandro Seawright Alonso *
\section{Resumo}

Neste artigo problematizei as memórias do capelão luterano Elio Eugênio Müller, a sua história de vida e parte da história militar do Serviço de Assistência Religiosa do Exército Brasileiro, SAREx, entre os anos de 1998 e 1999. Desde o serviço militar obrigatório no ano do golpe civil-militar de 1964, Müller tornou-se inclinado ao exercício da capelania militar no Exército Brasileiro. Em 1983, Müller ingressou na capelania militar e vivenciou situações de tensão dentro da Igreja Evangélica de Confissão Luterana no Brasil, IECLB. Anticomunismo, guerrilha do Araguaia, "tolerância religiosa", intolerância à homossexualidade entre capelães militares e o contexto da ascensão de Müller à chefia do SAREx são temas suscitados no presente artigo. Utilizo-me de documentos inéditos colocados ao lado da historiografia e de uma entrevista de história oral. Realizei discussões na perspectiva da escuta em história oral desde a memória de "expressão oral" do narrador que, com liames ousados, atravessa a "memória institucional" do Exército Brasileiro; tanto assim, que a história oral de vida ganhou dimensões produtivas no escopo do presente artigo.
\end{abstract}

Palavras-chave: História do Brasil República, História Militar, História Oral, Memória

\begin{abstract}
In this paper, I discuss the memories of the Lutheran chaplain Elio Eugênio Müller, his life story and part of the military history of "Serviço de Assistência Religiosa do Exército Brasileiro (SAREx)" - an army religious assistance service - between 1998 and 1999. Since 1964, when the military service became compulsory due to civil-military coup, Müller became inclined to the military chaplaincy in Brazilian Army. In 1983, Müller joined the military chaplaincy and experienced stressful situations in the Evangelical Church of Lutheran Confession in Brazil. Anticommunism, Araguaia Guerrilla, religious tolerance, homosexuality intolerance among military chaplains and the context in which Müller became the head of SAREx are issues presented in this article. I use unpublished documents placed aside the historiography and an oral history interview. I conducted discussions in the context of listening to oral history from the narrator's memory that has the "institutional memory" of the Brazilian Army; so that the oral history of life gained productive dimensions in the scope of this article.
\end{abstract}

Keywords: History of Republic of Brazil, Military History, Oral History, Memory

Artigo submetido em 24 de abril de 2016 e aprovado em 14 de dezembro de 2016.

* Pós-doutorando no Departamento de História da Universidade de São Paulo - FFLCH/USP. Doutor em História Social pela Universidade de São Paulo - FFLCH/USP. Foi pesquisador da Comissão Nacional da Verdade, CNV. É coordenador do Núcleo de Estudos em História Oral - NEHO/USP ao lado do Prof. Dr. José Carlos Sebe Bom Meihy. País de Origem: Brasil. E-mail: leandroneho@gmail.com

Horizonte, Belo Horizonte, v. 14, n. 44, 1589-1618, out./dez. 2016 - ISSN 2175-5841 


\section{Introdução}

Entre os anos de 1998 e 1999 o Serviço de Assistência Religiosa do Exército Brasileiro, SAREx, foi chefiado pelo capelão Elio Eugênio Müller (nascido a 12 de novembro de 1944 e falecido a 12 de março de 2016) ${ }^{1}$. Na condição de pastor da Igreja Evangélica de Confissão Luterana no Brasil, IECLB, o coronel reformado Müller foi o primeiro ministro protestante que ascendeu ao posto de chefe do SAREx durante o governo do ex-presidente da República Fernando Henrique Cardoso e na fase final do general Zenildo Gonzaga Zoroastro da Costa de Lucena como Ministro do Exército do Brasil (que compreendeu os anos de 1992 e 1999)². Em 1998, a dinâmica das sucessões na chefia do SAREx sofreu descontinuidade porque, pela primeira vez, os sacerdotes católicos, capelães do Exército Brasileiro, foram chefiados por um "irmão separado" - um pastor luterano3. Embora tenha chefiado o SAREx por um período breve, do dia $1^{\circ}$ de agosto de 1998 ao dia 31 de março de 1999, Müller demonstrou, por meio dos registros variados das suas memórias, que o Exército Brasileiro aderiu à certa retórica de "tolerância religiosa" no comando da capelania castrense - embora, reconheço, a sua ascensão à chefia do SAREx tenha se dado, sobretudo, em razão de ser o capelão mais antigo no exercício da função. Pretendo problematizar a noção de "tolerância religiosa" por meio dos registros mnésicos de Müller, e, igualmente, desnaturalizá-la com fulcro na análise dos "limites da tolerância" dos chefes militares. Assim, a problematização em evidência decorre da análise de um documento estabelecido a

\footnotetext{
${ }^{1}$ Para Ubiratan Nelson Crivelari (2008, p. 29), o "capelão militar é um ministro religioso encarregado de prestar assistência religiosa a alguma corporação militar" e existem "capelanias evangélicas e católicas, as quais desenvolvem suas atividades buscando assistir integrantes das Forças nas diversas situações da vida. O atendimento é estendido também aos familiares". As presenças de padres católicos e pastores protestantes na Força Expedicionária Brasileira, FEB, durante a II Guerra Mundial, foram marcantes e constam no Portal do SAREx na internet. No entanto, a Lei no 5,711, de 8 de outubro de 1971 reestruturou o Serviço de Assistência Religiosa nas Forças Armadas, SARFA; somente por meio da Portaria Ministerial no 995, de 9 de outubro de 1972, contudo, o Serviço de Assistência Religiosa do Exército - SAREx - como se tem atualmente - foi criado. Para complementar a legislação acerca da "assistência religiosa" no Exército Brasileiro, a Lei no 6.923, de 29 de junho de 1981, dispôs acerca do Serviço de Assistência Religiosa nas Forças Armadas. Depois disto, os capelães militares passaram a "integrar a oficialidade" de "carreira dentro das respectivas Forças" (EXÉRCITO BRASILEIRO, 2016).

2 O nominado "protestantismo de imigração", que, neste caso, refere-se ao luteranismo no Brasil, estabeleceu-se de forma paulatina conforme Antônio Gouvêa Mendonça e Prócoro Velasques Filho (2002, p. 27): "os imigrantes alemães foram se localizando progressivamente em vários pontos do país, além do interior das províncias do Rio de Janeiro e Rio Grande do Sul: Santa Catarina, São Paulo, Espírito Santo e Sul de Minas Gerais. Fundaram diversos sínodos que acabaram se unindo em 1938 e organizando, em 1949, uma Federação de Sínodos. A Igreja Evangélica de Confissão Luterana no Brasil (IECLB), que engloba todos esses órgãos regionais, obteve sua independência da Igreja Evangélica Alemã em 1955".

${ }^{3}$ Expressão utilizada pelo Decreto “Unitatis Redintegratio - sobre o ecumenismo". (PAPA PAULO VI, 1964).
} 
partir de uma entrevista de história oral com o capelão 4 e de documentos do SAREx fornecidos pelo interlocutor durante o nosso encontro na cidade de Curitiba ocorrido no dia 16 de setembro de 20145. Cabe definir que, a história oral é "um conjunto de procedimentos que se iniciam com a elaboração de um projeto”, mas continua com a escolha do entrevistado ou de um grupo de pessoas a serem entrevistadas (MEIHY; RIBEIRO, 2011, p. 12). Assim, faz parte do "conjunto de procedimentos" aventado por José Carlos Sebe Bom Meihy e Suzana Lopes Salgado Ribeiro, que reconheçam o “outro”, o "entrevistado”, em história oral, como sendo um "colaborador": "no momento da coleta das narrativas e na elaboração de textos escritos, dá-se uma espécie de fusão de propósitos entre quem relata e quem materializa o documento" (MEIHY; RIBEIRO, 2011, p. 23).

Os elementos da sua "história de vida" e das suas memórias são importantes tanto pela subjetividade apresentada na narrativa que se estabeleceu (PORTELLI, 1996), quanto pela abordagem historiográfica empreendida e por meio de análises da “documentação mnêmica" apresentada por Müller como "colaborador". A entrevista de história oral realizada com Müller pertence, ao lado de outras narrativas, ao corpus documental da pesquisa de doutorado que intitulei de "Ritos da oralidade: a tradição messiânica de protestantes no Regime Militar Brasileiro” (2016); a narrativa passou, em consequência disso, pelas diferentes etapas de seu estabelecimento por meio do "um conjunto de procedimentos", conforme o conceito demonstrado acima. Reconheço a pertinência da "história oral híbrida”, neste caso, porque produz a dialogia entre os “documentos mnésicos" e a

\footnotetext{
${ }^{4}$ Valendo-me da concepção de ética em pesquisa, das recomendações do Departamento de História da Universidade de São Paulo e, sobretudo, da ética em pesquisa de História Oral, lancei mão das indicações de Meihy e Holanda sobre a validade das entrevistas realizadas em minha pesquisa de doutorado: "a carta de cessão é um documento fundamental para definir a legalidade do uso da entrevista" (2013, p. 148). Recorrentemente, os pesquisadores do NEHO-USP - em suas pesquisas publicadas - usam os aportes éticos, jurídicos e procedimentais fornecidos pelo professor José Carlos Sebe Bom Meihy e aprovados pelo Departamento de História da Universidade de São Paulo. A entrevista em questão foi transcrita e tratada segundo os procedimentos da História Oral, bem como conferida pelo narrador que, ulteriormente, assinou a carta de cessão de direitos autorais prevista na legislação. Por fim, a banca de doutorado composta por José Carlos Sebe Bom Meihy (presidente), Leandro Karnal, Antonio Máspoli de Araújo Gomes, Marcos Napolitano de Eugênio e José Antônio Vasconcelos avaliou a documentação e a aprovou, recomendando a publicação da pesquisa. Este artigo é evidentemente inédito e se utiliza, porém, de suporte documental da tese: "Ritos da Oralidade: a tradição messiânica de protestantes no Regime Militar Brasileiro" (SEAWRIGHT, 2016). Na submissão do artigo a Horizonte foi anexada essa carta de cessão de direitos autorais assinada por Elio Eugênio Müller.

${ }^{5}$ Os documentos fornecidos pelo interlocutor em 16 de setembro de 2014 foram escritos por ele com base nas memórias de sua vida, de sua trajetória militar. Tais documentos, escritos em sequência no ano de 1999, receberam o título de JORNADAS NORDESTINAS.
} 
historiografia, assim como lança "a vida para dentro da própria história e isso alarga seu campo de ação" (THOMPSON, 1992, p. 44) ${ }^{6}$.

Ao apresentar as memórias de Müller e, em decorrência disso, alguns acontecimentos tensivos experimentados no interior de uma comunidade da IECLB e evidenciados na documentação, pretendo - sem que essa seja a intenção principal - demonstrar suscintamente os conflitos endógenos e exógenos de uma parte da denominação luterana, mas, principalmente, reconstruir os fios das memórias de Müller e da história recente da chefia do SAREx. Para tanto, o conceito de memória coletiva, em Maurice Halbwachs (1994), estabeleceu-se como um fundamento para as abordagens teórico-metodológicas em diálogo com o gênero da história oral de vida. Conforme Antonio Torres Montenegro, a história oral de vida

Estabelece um campo de resgate da memória. São experiências, acontecimentos, momentos que constituem as fontes de significados a serem revisitados. Diferentes são as entrevistas que têm como foco determinados temas, nas quais a preocupação básica são opiniões, pontos de vista, análises do entrevistado. Esse tipo de entrevista se caracterizará por uma construção em que predomina a racionalidade ou mesmo o discurso racionalizado do entrevistado (MONTENEGRO, 1993, p. 56)

E o tempo da memória não é o tempo da História, posto que se pode reconhecer "a seletividade como uma das características fundantes" do "conjunto mnêmico" (MONTENEGRO, 1993, p. 56). Não se recomenda, portanto, procurar pela "linearidade" e "conexão simples" entre os assuntos destacados em uma perspectiva mnésica alcançada por um texto de história oral: mesmo a linguagem com que se escreve é aquela da "história de vida", da "história comum", da "história vista de baixo" - distante do "academicismo". Da memória coletiva, Halbwachs disse que sinaliza para toda "lembrança que, por mais pessoal que seja, até as de acontecimentos de que apenas nós fomos testemunhas, até as de pensamentos e de sentimentos não expressos, está em relação com todo um conjunto de noções que muitos outros além de nós possuem”. Na memória coletiva estão: “pessoas, grupos,

\footnotetext{
"Meihy e Holanda consideram que a história oral híbrida é aquela que produz um "poder de conversa", "contatos" ou "diálogos" com outros documentos $(2013$, p. $128-130)$.
} 
lugares, datas, palavras e formas da linguagem, também com raciocínios e ideias, ou seja, com toda a vida material e moral das sociedades das quais fazemos ou não fazemos parte" (HALBWACHS, 1994, p. 38). Para apresentar os meandros da memória coletiva, Halbwachs acrescentou, em suas conceituações, a existência de “quadros coletivos” da memória, que são "elementos que induzem e organizam a lembrança individual". Esses "quadros coletivos" apoiam "pontos de referência no espaço e no tempo, noções históricas, geográficas, biográficas, políticas, dados da experiência corrente” - segundo a abordagem teórica de Danièle Hervieu-Léger e Jean-Paul Willaime (2009, p. 221). Por sua vez, o gênero da história oral de vida garante uma aproximação com a memória coletiva e permite

a independência dos suportes probatórios. As incertezas, descartabilidade da referenciação exata, garantem às narrativas decorrentes da memória um corpo original e diverso dos documentos convencionais úteis à História. Em particular, a história oral de vida se espraia nas construções narrativas que apenas se inspiram em fatos, mas vão além, admitindo fantasias, delírios, silêncios, omissões e distorções (MEIHY; HOLANDA, 2013, p. 34).

No gênero da "história de vida", admitem-se elementos subjetivos que podem ser cruzados com “documentos objetivos” ou "estáveis” em uma história oral híbrida, mas que têm relações com discursos que "dependem da memória" e seus "ajeites, contornos, derivações, imprecisões e até das contradições naturais da fala” como suportes hermenêuticos (MEIHY; HOLANDA, 2013, p. 35). Sem prescindir de uma abordagem com "fontes diversas", Lucien Febvre - citado por Jacques Le Goff - considerou a importância da construção de uma historiografia sustentada nos "documentos escritos", isto é, com o aporte de "documentos regulares" quando disponíveis para a análise do historiador. Mas primou, ao mesmo tempo, pela "engenhosidade do historiador" que, para "fabricar o seu mel", quando faltam "as flores habituais", utiliza-se de "palavras, sinais, paisagens e telhas", assim como das "formas de campo e com más ervas; com eclipses da lua e com arreios; com peritagens de pedras, feitas por geólogos e análises de espadas de metal, feitas por químicos". Assim, Febvre versou sobre a utilização de "múltiplas fontes", das “fontes orais", entre elas, e de "tudo o que sendo próprio do homem, 
dele depende, lhe serve, o exprime, torna significante a sua presença, atividade, gostos e maneira de ser" (FEBVRE apud LE GOFF, 2003, p. 219).

Distante, pois, de um "estudo linear", baseado em acontecimentos e no conceito clássico de "fato" como rígida sequência de acontecimentos, e na linha da "história de vida", bem como na temporalidade que se dobra e se desdobra da memória do narrador, os nexos - voltados às "formas de pensar" - entre as partes apresentadas neste artigo, contribuem para uma reflexão sobre as "ideias" de Müller, sobre os "caminhos" do SAREx. Mais do que uma "unidade lógica" contínua, ininterrupta, linear, pouco provável em uma narrativa de história oral de vida, busquei aquilo que o historiador Dominique Julia nominou de "mudanças", "permanências", "ideias”, “desejos”, "sentimentos”, “modificações”: lugares móveis em uma instituição militar aparentemente estável (LE GOFF; NORA, 1976, p. 106). Por isso, no presente artigo - no tempo da "história de vida" - o narrador organizou com a liberdade devida os assuntos da memória sem a interferência "autoritária" e "hierárquica" do autor como quem pretensamente "dá" a "versão correta", "conexa", "linear", "indefectível”. Sem dar voz, dei ouvidos.

Em "Do serviço militar obrigatório à capelania castrense: as memórias de Müller", almejei, dando ouvidos às "dicções de Müller", a "memória fundacional" da vida castrense e a origem da valorização de certa retórica da caserna; em "Xambioá, Xambioá, eu te vi lá: os lugares da memória e da história”, valorizei a narrativa da moldura ideológica de Müller - adquirida inclusive na caserna - em contato com uma "militante comunista", sobrevivente do Araguaia: fios trançados ajudaram a urdir uma explicação, na perspectiva da história, que se pergunta pelas "ideias" conforme supramencionei - os nexos entre as partes não são de simples ordenamento, porém seguem a tendência da "seletividade", da "afetividade" no âmbito da memória do narratário; em "Um "pastor alemão" na chefia do SAREx: religião, poder e os "limites da tolerância" na capelania do Exército Brasileiro", demonstrei como não somente Müller era "anticomunista" na polarização ideológica do ambiente da Guerra Fria, mas também como o capelão construiu 
institucionalmente o seu trajeto - sendo fundamental para as "relações de poder" da caserna. Tais relações e "valores morais", "(in)tolerantes", a serem salvaguardados no Exército Brasileiro - e entre clérigos - ficam explícitos no diálogo com o capelão Alberto da Costa Reis. Assim, a pergunta respondida na condução da escrita do presente artigo é: a partir da "história oral de vida", quais foram os eventos entrecruzados com a trajetória de Müller ao mesmo tempo essenciais para a formação do capelão e de um período alternativo no interior do SAREx? Isto é, como a “forma de pensar" de Müller, desde as origens de um "jovem militar” até a sua formação de oficial religioso do Exército Brasileiro, e mesmo no que tange ao "anticomunismo" exercido dentro de sua denominação religiosa, instruíram um tempo de austeridade no SAREx sob o "aspecto" da "tolerância" dos chefes castrenses? Com Montenegro (1993, p. 60), ressalto que para oferecer tais respostas se deve respeito ao tempo e ao lugar da memória, a qual é confeccionada em um "processo de universos imbricados", posto que "o tempo cronológico inexiste” porque: "o tempo da memória é o tempo da experiência de um período de vida, de atividade profissional, política, religiosa, cultural, afetiva... que nos arrebata e condiciona quase que inteiramente, nos fazendo perceber", nos fazendo "reconstruir a realidade de uma determinada maneira".

\section{Do serviço militar obrigatório à capelania castrense: as memórias de Müller.}

Assim que Müller atingiu a idade necessária para realizar o serviço militar obrigatório, disse para Hilda Müller, sua mãe, sem titubear: "quero servir o Exército!"; mas ela, por seu turno, procurou desencorajá-lo por temer a possibilidade de uma guerra: "não, meu filho, não vá, pois o Exército não é lugar para você”. Por meio da entrevista realizada, sabe-se que Müller nasceu no ano de 1944 - período final da Segunda Guerra Mundial - e a sua mãe se recordou da participação de jovens soldados na Força Expedicionária Brasileira, FEB (FERRAZ, 2002). Em Cruz Alta, no Rio Grande do Sul, estabeleceu-se o $17^{\circ}$ Regimento de Infantaria do Exército Brasileiro e Müller, da cidade gaúcha de Panambi, 
apresentou-se para o serviço militar naquele quartel. Percebe-se, em decorrência disso, que Müller se interessou inicialmente pela vida militar por causa do serviço obrigatório no ano tensivo de 1964, conforme se recordou o colaborador (DREIFUSS, 1981)7: "assim, em 1964 parti para servir à pátria no Exército Brasileiro [...] aliás, foi antes de iniciar a Revolução de 31 de março de 1964"8. Posteriormente, de soldado Müller foi promovido a cabo e, de forma regular, iniciou-se na vivência da caserna.

Segundo as lembranças de Müller, ele serviu “o Exército em 1964 com um clima de tensão no ar" em razão do ambiente da Guerra Fria e "havia um desenvolvimento de uma forma de consciência dentro do Brasil e do mundo, na realidade" - o "anticomunismo" (MOTTA, 2002). Com uma formação religiosa protestante, ortodoxa e anticomunista, Müller não hesitou em se posicionar: "quem foi soldado, sempre será soldado [...] eu era contra essa ideia de "cubanizar” o Brasil, de ir para Cuba, de ir lá para preparar líderes”. Para o narrador, a pretensão das esquerdas no país era a "subversão", a "criminalidade”, a "violência”, e, para isso, procedeu-se o "roubo de armas” em quartéis das Forças Armadas, assim como os "sequestros de autoridades" como constante na historiografia9. Para "defender a pátria” de seus "inimigos internos”, Müller, não distante da narrativa "ufanista”, ficou de "prontidão" por um período de dez meses consecutivos e, segundo ele se lembra, guarneceu pontos estratégicos de Cruz Alta ${ }^{10}$. A importância de Cruz Alta no contexto que considerou ser de uma defesa das ações das esquerdas - se destaca porque a cidade tinha conforme o colaborador: "centrais elétricas, com correios e com telégrafos, bem como com outras repartições públicas que eram visadas, atacadas”. Com os retraços característicos de sua “memória heroica”, Müller narrou

\footnotetext{
${ }^{7} \mathrm{Na}$ história oral como praticada pelo Núcleo de Estudos em História Oral, NEHO/USP, o entrevistado não é considerado simplesmente como um "depoente", um "informante", um "ator social" ou um "objeto de estudos", mas um colaborador. Para José Carlos Sebe Bom Meihy e Suzana Ribeiro, o "respeito ao significado da colaboração é um bom ponto de partida" para instruir iniciativas em história oral (2011, p. 23).

${ }^{8}$ Evidentemente, a utilização da expressão "Revolução" foi uma escolha do entrevistado.

${ }^{9} \mathrm{Na}$ historiografia especializada, porém, consta frequentemente não o termo "sequestro", mas "captura" de autoridades.

${ }^{10} \mathrm{O}$ ufanismo reporta à "ideia de nação" regida pela "força da pátria" que pode estabelecer "um estímulo para a guerra" ou para a "conquista" (BURNS, 1968, p. 3). Segundo Marilena Chauí, o conceito de "nação", conforme concebido por brasileiros, permite: "em certos momentos, crer na unidade, na identidade e na indivisibilidade da nação e do povo brasileiro, e, em outros momentos, conceber a divisão social e divisão política sob a forma dos amigos da nação e dos inimigos a combater" (CHAUÍ, 2001, p. 8).
} 
sobre uma situação de perigo e dita sobrevivência: "quando estava de serviço numa central elétrica, guarnecendo com meia dúzia - eu cabo, meia dúzia de soldados e mais um sargento, nós fomos atacados à noite"; durante o referido ataque, no lugar onde ele estava, uma bala disparada no escuro por guerrilheiros passou a dois centímetros de sua cabeça. O narrador contou que a bala não o atingiu, mas que: “o visado era eu que estava na luz porque os demais estavam protegidos [...] estive na mira de comunistas [...] eu estava me locomovendo para trocar a guarda... naquele momento, senti o quão difícil era a situação”.

Complementarmente, Müller classificou o golpe civil-militar de "A Redentora” em função de sua evidente conotação político-religiosa para defender que o movimento de "sublevação" e “insurgência” foi, antes, uma "Revolução Redentora da Pátria” (SEAWRIGHT, 2016, p. 127 - 145). Em sua narrativa, Müller preconizou que os militares estavam "interessados, sim, em barrar essa iniciativa que iniciou com gente treinada em Cuba, em China”, pois as esquerdas, segundo ele, estavam divididas em “diferentes facções terroristas, subversivas”. No entanto, os militares do Exército Brasileiro e das Forças Armadas permaneceram "unidos em torno da pátria” embora existissem “as várias linhas estratégicas militares” conforme o colaborador. O Millenial Day brasileiro proporcionou à Müller e para parte dos protestantes ortodoxos anticomunistas uma sensação de vitória contra o "império da maldade diabólica”, contra o comunismo do Jango "possuído" pelo Diabo das "Reformas de Base". Durante a sua luta em prol da chamada "defesa da pátria”, contudo, Müller se encontrou com um capelão militar do Exército Brasileiro que prestou assistência religiosa no Rio Grande do Sul em períodos de intervenção militar: era o "padre Dúlio Antônio Antonini” e, segundo disse, "nunca esqueço aquele homem bonachão, gaúcho, que tratava bem a todos, quer fossem católicos, quer fossem evangélicos”. Ainda que alguns soldados não professassem alguma religião, o capelão católico mencionado era - conforme se recordou Müller - “um paizão...”. Para firmar uma postura inicial de "tolerância religiosa", Müller, sem demora, mencionou que o capelão Duílio Antônio Antonini era bem humorado e deixava a todos muito confortáveis com as "histórias sobre o Antigo Testamento, 
sobre o Novo Testamento”. Embora Müller fosse um soldado “ortodoxo” e "anticomunista", almejou manter uma atitude distada do "anticatolicismo" propalado por uma parte dos protestantes conservadores no Brasil ${ }^{11}$. Ainda assim, Müller indagava à época do serviço militar obrigatório: "por que não existe um pastor evangélico como capelão, no quartel? Por que só padre?”.

Permaneceu, então, a certeza em Müller de que os capelães católicos tinham "um domínio muito acentuado sobre todas as coisas em nível nacional, em todas as repartições públicas e, particularmente, na capelania militar”. Nesse tempo, Müller passou a elaborar expectativas sobre o exercício do ministério pastoral luterano e, ao mesmo tempo, da capelania castrense. E Müller sabia da história da capelania no Brasil e da presença consolidada de sacerdotes católicos na assistência religiosa do Exército Brasileiro ${ }^{12}$. A maior parte dos integrantes das Forças Armadas, e, nesse caso, do Exército Brasileiro, é composta por clérigos que professam a fé católica, porém existe uma presença protestante crescente nas Forças Armadas do Brasil. Contudo, Müller pretendeu, a despeito disso, a carreira militar religiosa em semelhança do pastor metodista Juvenal Ernesto da Silva e do pastor batista João Filson Soren que não apenas inauguraram a "presença evangélica" no Exército Brasileiro, mas serviram entre os soldados da FEB nos anos de 1944 e 1945 - por ocasião da Segunda Guerra Mundial. Segundo Crivelari (2008, p. 38), a

capelania militar evangélica foi organizada pela extinta Confederação Evangélica do Brasil em conjunto com o governo brasileiro para assistir os militares protestantes. Entre os dois capelães elencados que participaram da Segunda Guerra Mundial, destaca-se o pastor batista João Filson Soren, pois seu trabalho foi tão majestoso em campos de batalha,

\footnotetext{
${ }^{11}$ Para Elizete da Silva (1999, p. 62 - 63), a "postura de anticatolicismo dos missionários não fora adquirida aqui no Brasil devido a posição majoritária do catolicismo. Movimentos anticatólicos que agitaram os EUA no século XIX e o ideal norte-americano de "Destino Manifesto" são as principais fontes que alimentam a hostilidade dos pioneiros batistas, não só contra a Igreja Católica como instituição, mas negando e ridicularizando a cultura e valores locais, vinculados ao catolicismo". No âmbito da argumentação do anticatolicismo, subjaz que a "Igreja Católica era responsável pelo atraso do Brasil, na ótica dos missionários" que primeiro pregaram supostos protestantes no país.

${ }^{12}$ A Capelania Militar Católica no Brasil é "garantida por força do acordo diplomático celebrado entre o Brasil e a Santa Sé, assinado no dia 23/10/1989". O Estatuto do Ordinariado Militar do Brasil, em seu Artigo 1ㅇ, refere-se ao "acordo feito entre a Santa Sé e a República Federativa do Brasil" como transcrito por Crivelari (2008, p. 30): O nominado "Vaticano Castrense no Brasil, ereto canonicamente, em 6 de novembro de 1950 e que, por força da Constituição Apostólica "Spirituali Militum Curae" de 21 de Abril de 1986, passou a ser Ordinariado Militar, depois do Acordo entre a Santa Sé e a República Federativa do Brasil, assinado em 23 de outubro de 1989, recebeu nova estruturação homologada pelo Decreto "Cum Apostolicam Sedem", de 2 de Janeiro de 1990, da Congregação dos Bispos" (ARQUIDIOCESE MILITAR DO BRASIL, 2016).
} 
marcando um período de 341 dias, participando do $1^{\mathrm{O}}$ Regimento de Infantaria - "Regimento Sampaio" [...].

Ainda que tenha elaborado de forma narrativa a "mitificação da memória" do capelão Soren como "herói da Guerra" e pioneiro na capelania militar protestante, Müller considerou, em sua entrevista, que depois das atuações inaugurais de Silva e Soren houve "uma ausência da presença de evangélicos no meio militar para o exercício do pastorado, para o exercício da capelania militar"; além disso, Müller disse que a lacuna provocada pela ausência dos ministros protestantes na capelania do Exército Brasileiro atraiu a sua "atenção em 1964" e, por isso, contou-me, ainda durante a entrevista, que se tratava de um marco em seu "despertamento vocacional”. Müller deixou o serviço militar obrigatório e, após certa "relutância", fez o curso de bacharelado em teologia na Escola Superior de Teologia, EST, em São Leopoldoํㅜㄹ A IECLB enviou Müller para o seu primeiro pastorado em Três Forquilhas, no Vale do Rio Três Forquilhas, no Rio Grande do Sul, em um lugar que ele: "não sabia nem que existia". Com isso, o narrador ingressou no pastorado de uma paróquia com 17 filiais em um "vasto espaço no litoral norte do Rio Grande do Sul, desde Torres até Osório, ou então, subindo a Serra de Cambará"14. Em Três Forquilhas, Müller permaneceu até o ano de 1975 como pastor local, mas, em seguida, pastoreou por pouco tempo uma comunidade religiosa em Sobradinho e, na sequência, permaneceu sete anos em outra comunidade luterana na cidade de Novo Hamburgo.

Em 1983, o colaborador soube que o Exército Brasileiro oportunizou uma vaga para a admissão de capelão protestante: “abriram vagas para capelães”, e, pela

\footnotetext{
${ }^{13} \mathrm{Em}$ 1920, em um artigo publicado pelo pastor Hermann Dohms, constatava-se a necessidade de formar "pastores familiarizados com a situação do país" e, então, em 1921 foi criado "um curso de formação humanística de ensino médio que se tornou, a partir de 1931, o Instituto Pré-Teológico - com sede própria no Morro do Espelho, São Leopoldo". Assim, em 1940 se iniciou um "curso teológico propedêutico" que teve de ser "interrompido em 1942" com a "declaração de guerra à Alemanha pelo Brasil". Depois da Segunda Guerra Mundial, criaram o "primeiro curso oficial de Teologia" e em 26 de março de 1946 foi "constituída a primeira "Escola de Teologia" da IECLB". Somente, porém, em 1984 a "Faculdade de Teologia passou a constituir a Escola Superior de Teologia", (ESCOLA SUPERIOR DE TEOLOGIA, 2016). Para Mendonça e Velasques Filho (2002, p. 28), a "Escola Superior de Teologia (EST) apresenta como auto-identificação e objetivos sua fidelidade à herança da Reforma luterana, abertura ecumênica e compromisso, na reflexão e na pesquisa, com as necessidades do povo brasileiro".

${ }^{14}$ Recordou-se Müller de que ele chegou solteiro em Três Forquilhas, mas casou-se com Doris Bobsin Müller - descendente do primeiro pastor luterano daquela colonização de 1826.
} 
primeira vez, conforme o narrador, admitiu-se que um pastor realizasse, juntamente com sacerdotes católicos, o curso de formação de oficiais na Academia Militar das Agulhas Negras, AMAN. Quando Müller soube da sua aprovação no concurso supracitado, por meio de um telegrama do Comando Militar do Sul, desligou-se rapidamente da comunidade religiosa local e se apresentou na AMAN para o início do curso de formação. Embora tenha almejado chegar ao posto de capelão militar quando conheceu o padre Dú́lio Antônio Antonini, e no tempo em que era um soldado do Exército Brasileiro, em 1964, Müller confidenciou-me: "jamais poderia esperar que isso acontecesse um dia em minha vida. Jamais poderia sonhar que pudesse chegar até lá”. Piedoso, Müller atribuiu o seu ingresso no curso de formação de oficiais capelães, na AMAN, ao que nominou de: “propósitos de Deus" e tendeu à "pregação religiosa” durante a entrevista: "não é tão simples como muitos pensam. Não é, assim, para se envaidecer, não é para ganhar medalhas, porque capelão não vai atrás de medalhas nem de postos”, porquanto a "vaidade não deve estar presente no peito do capelão militar". Na concepção de Müller, o capelão deve "ser sempre aquela expressão humilde do servidor que está de serviço principalmente dos mais fracos, do soldado mais pequenino que está lá na ponta mais curta da corda onde tudo arrebenta”.

Quando ingressou no curso de formação da AMAN, na fase de distensão da ditadura militar brasileira, Müller pretendeu manter uma "postura ecumênica" e de forma "negociada" - comum entre os protestantes teologicamente progressistas que aderiram à resistência armada ou não ao Regime Militar Brasileiro (comum, inclusive, entre os luteranos progressistas). No documento JORNADAS NORDESTINAS 1 (MÜLLER, 1999a), o colaborador manifestou a sua pretensão de “ser um capelão para todos”, isto é, não apenas para os militares luteranos, mas também para os outros protestantes e para os católicos. Registrou Müller, a partir de suas memórias, que:

A postura ecumênica é uma necessidade, diante da variedade de credos e escassez de capelães nas Forças Armadas. Já por ocasião do meu ingresso no SAREx, em 1983, avaliei a situaçã e concluí que era bem mais Interessante ter acesso a todos os soldados para prestar assistência, ao 
invés de reunir alguns "gatos pingados" evangélicos. Durante o Estágio na AMAN o coordenador de estágio quis colocar apenas os não católicos à minha disposição, para a minha primeira palestra no meio militar. Reclamei, alegando que não existia lógica ao tentarem colocar diante de mim luteranos, pentecostais, batistas, espíritas, adeptos da macumba e indefinidos. Por que não incluir logo também os católicos, pois a dificuldade seria a mesma, diante da miscelânea de crenças? Os dois padres que faziam o estágio comigo, foram consultados. A princípio discordaram, alegando que a Igreja Católica tinha seus capelães, para cuidar dos católicos e que não convinha que um pastor concedesse assistência para os mesmos. Foi então consultado o Padre Dúlio Antonini, capelão da AMAN, um gaúcho que fora meu capelão no $17^{\circ}$ RI, em 1964 (quando prestei o Serviço Militar, na cidade de Cruz Alta - RS). Padre Duílio atendeu o meu pedido, fazendo até questão de ouvir a minha palestra. Ele é que me apresentou ao efetivo, concordando assim de que não se faria separação por credo. Ele convocou os dois padres estagiários, para, também, estarem presentes à palestra. (MÜLLER, 1999a, p. 6 JORNADAS NORDESTINAS 1).

Na ocasião de seu reencontro com o capelão Duílio Antônio Antonini, e da manutenção da aludida "postura ecumênica” com a ajuda do padre, Müller decidiu documentar fotograficamente a circunstância considerada importante na fase inicial de sua trajetória como capelão do Exército Brasileiro:

\section{Figura 1: Major Capelão DUILIO ANTONINI e o Aspirante Capelão ELIO E. MÜLLER e os filhos do pastor CARLOS AUGUSTO e CRISTIANE, na AMAN.}

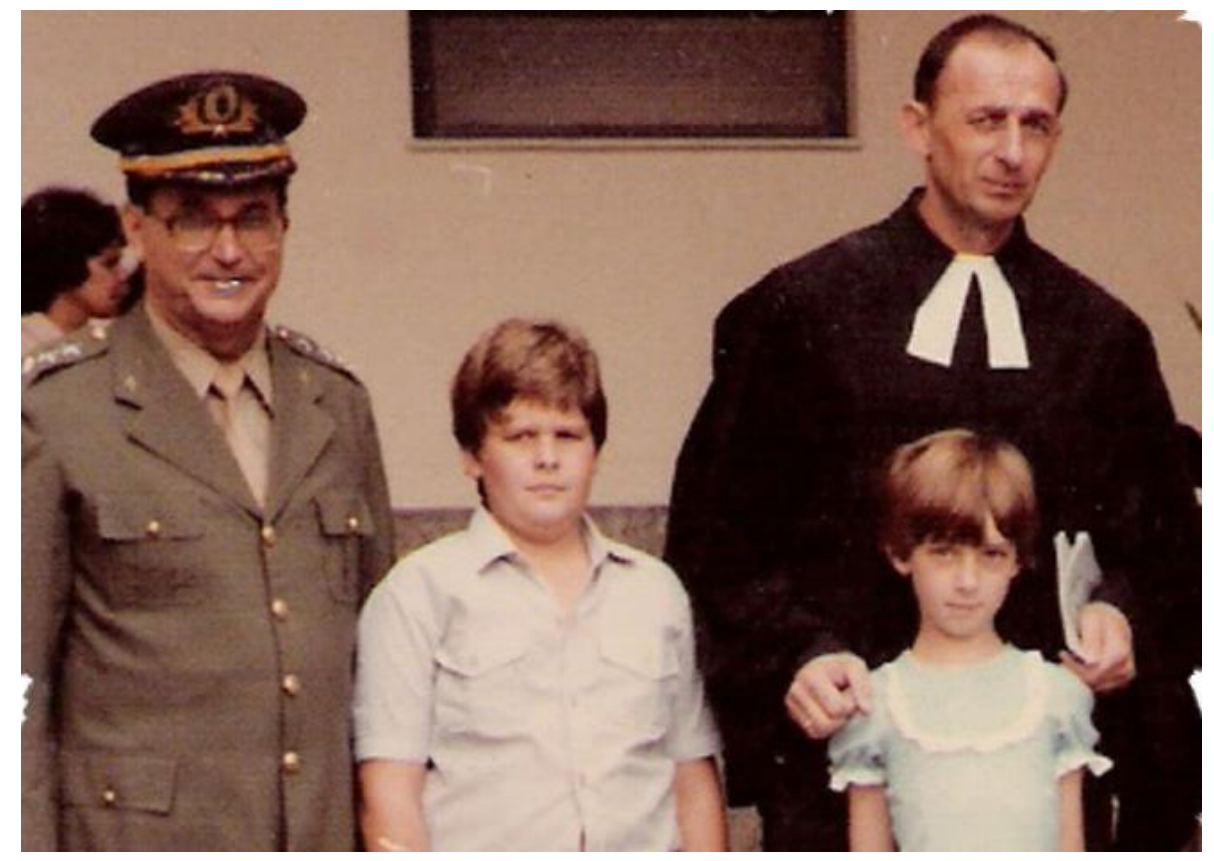

Fonte: Foto do acervo de Müller em “Jornadas Nordestinas 1" (MÜLLER, 1999a). 


\section{2 “Xambioá, Xambioá, eu te vi lá”: os lugares da memória e da história.}

No decurso da sua carreira como capelão do Exército Brasileiro, Müller serviu em Curitiba, no Estado do Paraná, de 1983 a 1994 (na $5^{\text {a }}$ Região Militar); serviu em Recife, no Estado de Pernambuco, de 1994 a 1998 (no Comando Militar do Nordeste); por fim, serviu em Brasília, no Distrito Federal, entre 1998 e 1999 (na chefia do SAREx). No dia 16 de junho de 1995, Müller participou de um conclave regional do Distrito Eclesiástico Norte-Nordeste, DENONE, da sua denominação, em Belém, no Estado do Pará. Ladeado por sua esposa, Müller dirigiu-se ao templo da Paróquia Evangélica de Confissão Luterana em Belém:

Fomos recebidos por uma equipe, de recepção. Quando fui apresentado, os meus dados para uma senhora que me atendia, ela teve uma reação inesperada de nervosismo. Ela quis saber: você é o pastor que trabalha para o Exército? Com a maior boa vontade expliquei: o meu trabalho é da Igreja, no Exército. Ingressei nas fileiras do Exército, sim, para atuar na Capelania Militar (MÜLLER, 1999b, p. 2 - JORNADAS NORDESTINAS 2).

Atemorizada, aquela líder leiga luterana olhou para Müller com o "semblante modificado", e, segundo ele, com o "horror" explícito em sua face ${ }^{15}$. Ela, então, afirmou em "tom de denúncia”: “Xambioá, Xambioá, eu te vi lá!”. Mas, Müller descreveu a sua surpresa:

Surpreso, olhei para essa senhora. Falei lentamente, para me certificar, de que eu estava ouvindo corretamente o que ela me dizia. Perguntei: "A SENHORA... ME... VIU... EM... XAMBIOÁ?... ISTO FOI EM 1972?... EM 1973?... OU EM 1974...” Ela movimentou afirmativamente a cabeça. Ela confirmava de que ela havia, realmente, me visto em Xambioá em um daqueles anos que eu citara (MÜLLER, 1999b, p. 2 - JORNADAS NORDESTINAS 2).

Logo Müller compreendeu que aquela fiel leiga de sua denominação, cujo nome foi preservado pelo capelão, havia afirmado, sem espaço para dúvidas, que

\footnotetext{
${ }^{15}$ Busquei saber o nome daquela líder leiga luterana presente no conclave luterano do DENONE não apenas para mero registro, mas para entrevistá-la. Não obtive sucesso, porém.
} 
ele participou da guerrilha do Araguaia em Xambioá, atualmente no Tocantins ${ }^{16}$. Antes de argumentar em seu próprio favor, Müller se recordou de que "em Xambioá muitos guerrilheiros e alguns soldados do Exército" perderam "a vida em confrontos na selva" e, curiosamente, admitiu: "muitos guerrilheiros haviam sido presos e que em Xambioá, quase todos, foram torturados” (MÜLLER, 1999b, p. 2 JORNADAS NORDESTINAS 2)17. A literatura especializada sobre a luta armada e mesmo os registros jornalísticos sobre a guerrilha do Araguaia traduzem dramas distintos, narrativas trágicas e tramas variadas no conflito entre guerrilheiros e militares vencido pelo Exército Brasileiro18. Entre Marabá e Xambioá, o "PCdoB pôde em suma, concentrar recursos humanos e materiais na estruturação da sua base guerrilheira, no que revelou à margem esquerda do rio Araguaia, no sul do Pará, um grupo de militantes com treinamento na China” - segundo Jacob Gorender; entre eles, estavam: Osvaldo Orlando da Costa (Osvaldão), João Carlos Haas Sobrinho, André Grabois, José Bronca e Paulo Mendes Rodrigues ${ }^{19}$. Paulatinamente, "sobretudo a partir de 1970, chegaram outros militares e atingiu o total de 69, dispersos ao longo de um estendido de Xambioá (GO) até Marabá (PA)” (GORENDER, 1987, p. 234). Sabe-se, por meio da historiografia, que "a guerrilha do Araguaia teve lugar nas regiões sudeste do Pará e norte do então estado de Goiás (atual Tocantins), abrangendo também terras do Maranhão, na área conhecida como Bico do Papagaio". Ressalta-se que ocorreu "entre meados da década de 1960, quando os primeiros militantes do Partido Comunista do Brasil (PC do B) chegaram à região - o lendário Osvaldão, em 1966 -, e 1974, quando os últimos

\footnotetext{
${ }^{16}$ Conforme o relatório da Comissão Nacional da Verdade, CNV, em 1966 e 1967 "os primeiros membros do partido chegaram ao sul do Pará, sendo o primeiro o próprio Oswaldo Orlando da Costa, já sob o codinome de Oswaldão" (BRASIL, 2014a. p. 683).

${ }^{17}$ Após seis anos da "chegada dos primeiros militantes comunistas, em 12 de abril de 1972, os enfrentamentos diretos teriam início na região da área de campo no sudeste do Pará". E eram 69 "guerrilheiros, espalhados por uma área de cerca de $6.500 \mathrm{~km}^{2}$, que cobria os principais municípios e vilarejos do sudeste do Pará, com as proximidades da cidade de Marabá, São Domingos do Araguaia, São Geraldo do Araguaia, São Sebatião, Araguatins, Toncatinópolis, Xambiolá e Brejo Grande do Araguaia" (BRASIL, 2014a, p. 685).

${ }^{18}$ Entre outros textos historiográficos e jornalísticos, evidencio os seguintes: "A Ditadura Escancaradas, as llusões Armadas" (GASPARI, 2002), "Combate nas Trevas" (GORENDER, 1987), "Guerrilha do Araguaia: a esquerda em armas" (PESSOA, 1997), "Operação Araguaia: os arquivos secretos da guerrilha" (MORAIS; SILVA, 2005), "Guerra de Guerrilha no Brasil: A Saga do Araguaia, Nova entrevista de José Genoino" (PORTELA, 2002), "A Lei da Selva: estratégias, imaginário e discurso dos militares na Guerrilha do Araguaia" ( STUDART, 2006), "Xambioá: guerrilha no Araguaia" (CABRAL, 1993), "Mata! O Major Curió e as guerrilhas no Araguaia" (NOSSA, 2012).

${ }^{19}$ Segundo Dênis de Moraes (2011, p. 71 - 72), o "alinhamento do PCdoB com a China foi enfatizado por Maurício Grabois no jornal Classe Operária, em julho de 1963. Ele enquadra o Partido Comunista Chinês como "destacamento de vanguarda e força dirigente da revolução mundial"; concomitantemente, Moraes transcreveu um excerto de João Amazonas, em 1979, cujo propósito era demonstrar a aproximação do PCdoB com Mao Tse-tung e os maoístas.
} 
guerrilheiros foram caçados e abatidos por militares”, preparados para combater a guerrilha do Araguaia sem, porém, deixar muitos remanescentes (PEIXOTO, 2011, p. 480). Conforme Jean Rodrigues Sales, o PCdoB lançou, antes, "o documento que propunha a definir sua tática de luta armada" e se tratava de "Guerra popular Caminho da luta armada no Brasil" por meio do qual se compreendeu que o melhor viés seria o "militarista":

Foi nessa situação que o PCdoB chegou ao início da década de 70 e à guerrilha do Araguaia, deflagrada em 1972. Nessa experiência, seu projeto de luta armada foi colocado à prova contra o Exército brasileiro [...] Mistura de guerra popular e foquismo, não teve melhor sorte que os projetos dos grupos armados nas cidades. Em 1974 quase todos os participantes haviam sido assassinados pelo Exército Brasileiro. (SALES, 2007, p. 87).

Mas, Müller, por seu turno, defendeu-se dos argumentos de quem chamou de "a senhora Xambioá" - uma sobrevivente luterana dos conflitos armados do Araguaia; ao reconhecer as violações do Exército Brasileiro e as mortes ocorridas em Xambioá, em Marabá, e em todo o território da guerrilha do Araguaia, Müller perguntou: "mas o que eu tinha a ver com esse fato?”. E explicou em sua defesa: “eu não estivera lá”, pois "entre 1972 a 1974 eu estivera atuando no vale do Rio Três Forquilhas, como pastor da IECLB para o Litoral Norte do Rio Grande do Sul”. À época da guerrilha do Araguaia, Müller não estava no Exército Brasileiro, porque retornou às fileiras militares apenas no ano de 1983 como aluno da AMAN. A líder leiga luterana que sinalizou para a presença de Müller em Xambioá havia sido presa em uma base militar no local segundo o pastor luterano pároco em Belém do Pará, Andreas Nuffer: "sei que uma das nossas líderes esteve na prisão, em Xambioá”. Durante o concílio do DENONE, em 1995, aquela líder leiga luterana de Belém do Pará, segundo Müller, se "assemelhava a uma fera acuada, como que estivesse pressentindo algum perigo iminente": tratou-se não somente de um enfrentamento característico do período pregresso da Guerra Fria sentido tardiamente, mas das memórias reelaboradas a posteriori. 
Para além da concretude do "fato histórico" nas disputas entre "estar" e "não estar” em Xambioá, a problematização das "memórias acirradas” - no período atingido pelo clima tardio da Guerra Fria - denota que os interstícios mnemônicos entre os lugares do "real-histórico" ou do "real-imaginado" são simbólicos e simbolicamente amoldados por "memórias subterrâneas" que emergem em disputa política, ideológica, espacial nas categorias de Michael Pollak (1989). Os encontros entre a historiografia e a memória - opostos que se atraem e se repelem - são fundamentais para se designar os sentidos do "real-histórico" como factual, concreto, "provável" ou do "real-imaginado" como lembrado, simbólico, “improvável”. A chamada "senhora Xambioá” disse que Müller "estava lá" e se recordou, com os retraços do "real-imaginado", de sua presença na guerrilha do Araguaia, pois o "espaço do lembrado", diante da leitura estritamente factual, reorganiza-se a partir do "vestígio mnésico" conforme preconizado por Michel de Certeau:

Assim, a história seria "canibal", e a memória tornar-se-ia o recinto fechado em que se opõem duas operações contrárias: por um lado, o esquecimento, que não é uma passividade nem uma perda, mas uma ação contra o passado; e, por outro, o vestígio mnésico, que é o retorno do esquecido, ou seja, uma ação desse passado, daqui em diante forçado ao disfarce. (DE CERTEAU, 2011, p. 71 e 72).

Se na escrita da história se estabelece um "corte entre o passado e o presente", bem como se trava relações "de saber e de poder", o "retorno do esquecido" - nos caminhos incertos da memória - refaz o "excluído" que "insinuase, de novo, neste lugar "limpo" ["propre”], instala-se aí, suscita a inquietação, torna ilusória a consciência segundo a qual o presente julga estar em "sua casa", fixa aí seu esconderijo": esse "selvagem”, esse “ob-sceno", esse "lixo", essa "resistência” da "superstição" vai "inscrever aí - à revelia do proprietário (o ego) ou contra ele - a lei do outro". Sem aderir, contudo, ao modelo do "enquadramento" histórico por uma “verdade” estritamente psicanalítica, reconheço as relações da história com a psicanálise, assim como da memória com a psicanálise conforme abalizas por De Certeau. Porque “a psicanálise e a historiografia têm, portanto, 
duas maneiras diferentes de distribuir o espaço da memória; elas pensam, de modo diferente, a relação do passado com o presente”, pois a psicanálise reconhece "um no outro" (passado no presente), e, por sua vez, a história coloca "um ao lado do outro”. São “estratégias do tempo”, são perspectivas de temporalidades:

A psicanálise trata essa relação segundo o modelo da imbricação (um no lugar do outro), da repetição (um reproduz o outro sob uma forma diferente), do equívoco e do quiproquó (o que está "no lugar" de quê? Há, por toda parte, jogos de máscaras, de reviravolta e de ambiguidade). Por sua vez, a historiografia considera essa relação segundo o modelo da sucessividade (um depois do outro), da correlação (maior ou menor grau de proximidade), do efeito (um segue o outro) e da disjunção (um ou outro, mas não os dois ao mesmo tempo). (DE CERTEAU, 2011, p. 72).

Nesse imbróglio do "ele estava lá" e do "eu não estava lá", o concílio do DENONE, conforme referido, foi classificado por Müller como "um misto de confusão e desorganização" por causa das diferentes razões apresentadas no registro de memórias JORNADAS NORDESTINAS 2 (MÜLLER, 1999b). Por isso, Müller abalizou que o pastor Andreas Nuffer, e parte dos fiéis da comunidade religiosa de Belém do Pará, utilizaram-se de "hostilidade como uma ferramenta permanente, contra a minha pessoa, pelo principal motivo, de eu ser um pastor do meio militar". Do ponto de vista histórico, entre outras coisas, estabeleceram-se os resíduos da dita tensão característica da Guerra Fria entre aqueles que se afeiçoaram ou se engajaram ideologicamente ao lado dos comunistas e aqueles que apoiaram ou ingressaram na vida militar. Os embates entre Müller e os membros do conclave revelaram entraves maiores no interior da IECLB nas categorias de Rolf Schünemann (1992).

Ao mesmo tempo em que não se tem suporte documental e evidências de que Müller estava em Xambioá, à época da guerrilha do Araguaia, sabe-se que os "lugares da memória" são outros e variáveis: eles se adéquam às narrativas de contestação em relações de poder complexas. A memória coletiva faz que uma lembrança se apoie na outra no interior de uma complexa "malha social": ainda que não haja evidências de que Müller estivesse "histórica" e "fisicamente" presente, por meio de outros militares, combatentes do Exército Brasileiro estava 
representado: então, a "memória escorrega", se torna "fluída" e deságua no oceano do imaginário - uma elaboração alternativa da "verdade", uma forma de "resistência" frente ao silêncio da sociedade. Reconhecidamente, não "há, com efeito, grupo, nem gênero de atividade coletiva, que não tenha qualquer relação com um lugar, isto é, com uma parte do espaço" - segundo Halbwachs (1994); para exemplificar, compreende-se que "todo quadro tem, com efeito, uma moldura, mas não há qualquer relação necessária e estreita entre uma coisa e outra, e a moldura não pode evocar o quadro". No entanto, o "espaço físico" não é suficiente - com suas "formas" e "colorações" para se interpretar o contexto das memórias - de sua "não-fixidez", de seu conteúdo "imagético", de seus "vestígios mnésicos" reelaborados e das relações de poder que se impõem entre o esquecimento e a recordação do "ele estava lá" - no caso de Müller e da líder leiga luterana que o interpelou no conclave do DENONE.

\section{Um "pastor alemão" na chefia do SAREx: religião, poder e os "limites da tolerância" na capelania do Exército Brasileiro.}

Quando Müller ingressou como oficial capelão do Exército Brasileiro, no ano de 1983, era a fase final do Regime Militar: "quero registrar ainda que, talvez, no meu primeiro momento como oficial, eles me apelidaram de "pastor alemão" porque se lembraram do general Geisel que era luterano assim como eu sou". Recordou-se Müller que "tentaram dar ao presidente Geisel o apelido de "neto de pastor alemão" - porque era neto de pastor luterano alemão. Porém, não pegou" ${ }^{20}$. Mas, o colaborador é descendente de alemães e pastor da IECLB - uma igreja fundada por imigrantes e considerada como "protestantismo de imigração", pois, segundo Mendonça e Velasques Filho (2002, p. 28), a "IECLB, como toda a comunidade luterana no Brasil, tem sido considerada Igreja de etnia - Igreja de alemães e seus descendentes". Por isso, Müller contou que quando ingressou na

\footnotetext{
${ }^{20}$ Antes de falecer em 1996, Ernesto Geisel e a sua família se transferiram para a Paróquia Luterana Bom Samaritano no Bairro de Ipanema, no Rio de Janeiro. O pastor Mozart Noronha - militante político ligado a AP e exilado político à época do Regime Militar recebeu, porém, Geisel e a sua família. Quando Geisel faleceu e Mozart Noronha fez o ofício fúnebre, fez questão de dizer: "fiz o sepultamento de Geisel e não a sua ressurreição" (SEAWRIGHT, 2016, p. 333 - 339).
} 
AMAN foi reconhecido, evidentemente, como pastor de "origem alemã", e, conforme disse, juntaram "pastor Müller" com "alemão" e "deu pastor alemão".

No início da sua trajetória como capelão militar, Müller serviu em Curitiba que, segundo ele, era um "reduto dos evangélicos no Paraná e em Santa Catarina". Em sua entrevista, o colaborador apresentou a sua trajetória: "da minha Igreja, então, em Blumenau, Joinville, havia grandes comunidades e até mesmo no norte do Paraná, mesmo em Curitiba"; por isso, Müller se sentia, como disse durante a entrevista, num "ninho de gente" da sua própria denominação de fé: "só que, para a minha surpresa, o Exército, para me testar, mandou-me para que lugar? N-o-r-d-es-t-e, Nordeste! Eu, um pastor luterano! Mandaram-me para o Nordeste onde eu era alguém totalmente fora da situação...”. No Nordeste, o colaborador se tornou "subchefe em nível nacional da Bahia até Maranhão em 1994". Neste mesmo ano, Müller foi promovido à tenente-coronel e me disse que foi ao Recife em uma das suas visitas a capelães e aos quartéis do Exército Brasileiro no Nordeste. Em Recife, o colaborador reencontrou o monsenhor Alberto da Costa Reis - primeiro capelão chefe do SAREx. Com cerca de 80 anos de vida, o capelão reformado Alberto da Costa Reis celebrava corriqueiramente missas na Igreja Nossa Senhora da Conceição dos Militares e Müller, por seu turno, o visitava nas celebrações católicas conforme me disse: "eu caprichei porque em, pelo menos, cada duas semanas ia visitá-lo na Rua Nova, no Recife, na Igreja onde ele rezava missas”. Então, Alberto da Costa Reis, que era amigo do Ministro do Exército Zenildo Gonzaga Zoroastro de Lucena, costumeiramente provocava Müller à reflexão: "quando você for chefe do SAREx, você vai fazer isto, você vai fazer aquilo”. No entanto, Müller não considerava a hipótese de ascender à chefia do SAREx sendo um protestante: "eu olhava para ele e perguntava: o quê? Você está apostando que eu vou chegar, onde não se pode chegar? Ninguém, nenhum evangélico pode ser chefe do SAREx!”.

Para apresentar tal complexidade e presença majoritária de católicos no Exército Brasileiro na década de 1990 - que está em evidência no presente artigo Crivelari considerou o censo daquela década: 
Destaca-se que só dentro do Exército Brasileiro a porcentagem do efetivo é de $68,2 \%$ de católicos e $23,22 \%$ de evangélicos. Se também forem considerados os familiares desses militares e os funcionários civis dos Ministérios, Policiais Militares Estaduais e Corpo de Bombeiros, chega-se ao universo de cerca de três milhões de pessoas. (Crivelari, 2008, p. 31).

Em 1998 - com um contingente de protestantes em fase de crescimento Müller se tornou coronel e, então, chefe do SAREx. Por isso, o colaborador aduziu que a "profecia", como preferiu chamar, de Alberto da Costa Reis se cumpriu. Contudo, Müller ponderou que, antes de sua promoção, inquietou-se: "estava pensando meio chateado: se eu for preterido, como o mais antigo, tenho mesmo que ir para a casa e ficar na reserva...". Dessa forma, se Müller fosse "preterido", seria - conforme me confidenciou - uma mostra aclarada de "intolerância religiosa" porque era um luterano: "os católicos ainda ditavam as regras", disse-me o colaborador. Ainda assim, diversos generais, tais como Leite e Molinaro, encorajaram-no a prosseguir sem passar à reserva: "não, não vá para a reserva, espere, tenha confiança, espera" - disse Molinaro21. Particularmente, Molinaro afirmava para Müller, ao sustentar um "dito popular", para encorajar o colaborador: "o que é do homem o bicho não come - espera!". Quem "costurou", entretanto, a ascensão de Müller à chefia do SAREx foi Alberto da Costa Reis que segundo o narrador - era "amigo do general Zenildo", e, inclusive, realizou a cerimônia matrimonial do Ministro. Sem comedimentos sobre as "relações dos bastidores castrenses", Müller me explicou: "houve diálogo de bastidores entre eles" e se anunciou: "promovido a coronel Elio Eugênio Müller, do Recife, e nomeado novo chefe do SAREx".

No registro de memórias JORNADAS NORDESTINAS 5 (MÜLLER, 1999c), consta um diálogo entre Alberto da Costa Reis e Müller no ano de 1997 - um ano antes do colaborador ascender à chefia do SAREx. Apresentaram-se problemas relevantes para a presente pesquisa, pois as relações de poder entre padres católicos e pastores protestantes foram constatadas na capelania militar do

\footnotetext{
${ }^{21}$ Não foi possível determinar os nomes completos de Molinaro e Leite.
} 
Exército Brasileiro. Porque, com Michel Foucault, considero que "as relações entre indivíduos são, eu não diria antes de tudo, mas são em todo caso, também relações de poder”, pois, para o autor, "toda relação humana é a um certo grau uma relação de poder" (2001, p. 1193 e 1666). Assim, onde "há poder, ele se exerce" e "ninguém é, propriamente falando, seu titular; e, no entanto, ele sempre se exerce numa determinada direção, com uns de um lado e outros de outro" (FOUCAULT, 1994, p. 75).

Algumas partes do diálogo entre Alberto da Costa Reis e Müller, constante em JORNADAS NORDESTINAS 5 (MÜLLER, 1999c), foram escolhidas para a análise:

Alberto da Costa Reis - Hoje eu quero que você passe a entender porque você precisa chegar à chefia do Sarex.

Müller - Também estou curioso. Já tentei imaginar os seus motivos de querer isto, mas, não chego a nada.

Alberto da Costa Reis - É simples. Você é evangélico.

Müller - Já sei. Vai alegar que com isto o Exército dará uma prova de que valoriza a liberdade de fé?

Alberto da Costa Reis - Até seria um argumento. Mas não é isto. Você sabe que os padres capelães ficaram muito desgastados nestes últimos anos. Todos só olham para aqueles que tiveram problemas. Fala-se de que os padres só têm problemas. E evangélico não?

Müller - Não consigo captar o seu raciocínio.

Alberto da Costa Reis - Você terá que servir como demonstração clara de que um não é melhor do que o outro. Você não é melhor e nem pior que o padre...”.

Müller - Ainda não entendi.

Alberto da Costa Reis - Ora, preciso dizer em claro e bom tom? Ser evangélico não é melhor que ser católico. Todos têm suas falhas, pois que todos pecaram e carecem da glória de Deus.

Müller - Essa mudança estrutural, no seu entender, salvará o SAREx da ruína?

Alberto da Costa Reis - Observe bem. De um lado está a Igreja Católica lutando para se manter como a dona do terreno. Do outro lado estão os evangélicos, lutando contra católicos. Os evangélicos começaram a exigir garantias de espaço e lutam contra as pretensões católicas. Além disso, não se deve esquecer que aí também estão os espíritas, insatisfeitos, e reclamando. À margem desse teatro de lutas estão aqueles que não acreditam mais em nada ou já se desiludiram das Igrejas. Esses ficam rindo e debochando dos padres e dos pastores, com razão. (MÜLLER, 1999c).

Por suposto, Alberto da Costa Reis estava convicto que Müller deveria assumir a chefia do SAREx não somente com base no argumento da "tolerância 
religiosa", mas porque, em primeiro lugar, havia um "desgaste" dos capelães católicos devido a problemas políticos e institucionais não suficientemente apresentados no documento. Em segundo lugar, Alberto da Costa Reis pretendeu demonstrar por meio da ascensão de Müller à chefia do SAREx que um pastor protestante não era melhor que um padre, porque, teologicamente, todos são "pecadores" que precisam da "glória de Deus" - conforme a ortodoxia. Em terceiro lugar, Alberto da Costa Reis admitiu haver uma tensão agravada institucionalmente entre os católicos e os protestantes, e, nesse sentido, a Igreja Católica se considerava logicamente a "dona do terreno" no Exército Brasileiro. Por isto, os capelães protestantes estavam exigindo consequentemente um "espaço institucional alargado" para demarcar a presença protestante no Exército Brasileiro. Na mesma medida, o SAREx, segundo o diálogo apresentado no documento, estava em "risco" porque, entre outras coisas, as "relações de poder" entre católicos e protestantes se acirraram na década de 1990. Assim, Alberto da Costa Reis e seus interlocutores almejaram que o SAREx fosse um "Serviço de CRISTO, para TODOS, conforme nosso Senhor JESUS CRISTO ordena, e basta" segundo consta em JORNADAS NORDESTINAS 5 (MÜLLER, 1999c); para eles, Müller era o capelão mais antigo do Exército Brasileiro e representava uma oportunidade de "apaziguamento" no campo político-institucional tensivo dos religiosos daquela Força. Por fim, e em quarto lugar, Alberto da Costa Reis revelou - em diálogo com Müller - o descontentamento dos "chefes militares" com a “orientação sexual” de uma parte dos capelães católicos à época:

Alberto da Costa Reis - "Não fique divagando em pensamentos teológicos. Olhe para a questão prática, que expus a você. Você tem uma tarefa a ser cumprida. Basta que você seja o que é e assuma a Chefia e, nunca mais as coisas poderão retornar ao que eram ou ao que foram até aqui. O nosso Bispo castrense será confrontado com esta nova realidade e, os nossos chefes militares sei que desejam ver isto acontecer. Os chefes militares não estão satisfeitos com o SAREx... Eles reclamam da conduta e da vida que muitos dos capelães estão levando; Basta lembrar a questão da sexualidade (ou a homossexualidade e promiscuidade, abraçada por muitos padres. Você já socorreu alguns deles e os assistiu, ajudando-os a sair da promiscuidade deplorável...)”. (MÜLLER, 1999c). 
Segundo as memórias de Müller sobre a conversa com Alberto da Costa Reis, ele mesmo se tornou um conselheiro de capelães católicos homossexuais. Conforme consta no documento, os capelães católicos homossexuais eram "promíscuos" - nos ditames da moral religiosa ortodoxa sustentada pelas igrejas Católica e Luterana no Brasil. Despontaram-se, pois, os "limites da tolerância" de "chefes militares", do "topo da hierarquia", e, não obstante, de capelães ortodoxos que defendiam ao mesmo tempo uma postura ecumênica no convívio entre militares cristãos. Dessa forma, a ascensão de Müller à chefia do SAREx foi uma demonstração de que a "hegemonia político-institucional" dos capelães católicos estava ameaçada por razões variadas e, sobretudo, por causa da intolerância das Forças Armadas do Brasil aos militares que são religiosos e ao mesmo tempo homossexuais.

Figura 2: Os capelães Alberto da Costa Reis e Elio Eugênio Müller.

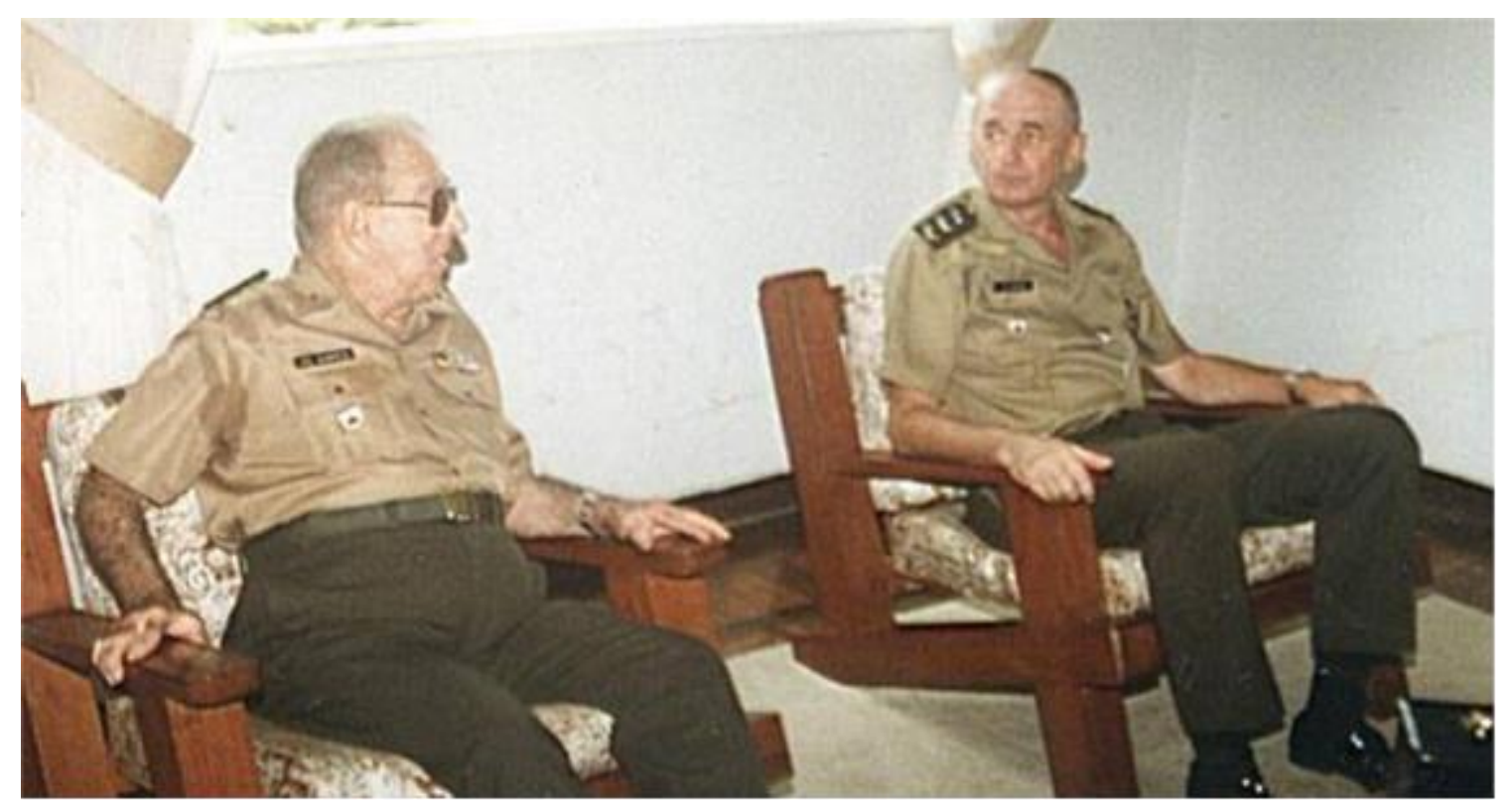

Fonte: Foto do acervo de Müller em “Jornadas Nordestinas 1” (MÜLLER, 1999a).

Segundo Helena Carreiras (2004, p. 63), a "integração de mulheres, minorias étnicas, homossexuais, minorias religiosas ou linguísticas nas Forças Armadas passou a constituir objeto de enorme atenção por parte das chefias militares e também dos cientistas sociais" nas últimas décadas. Em análise sobre as 
Forças Armadas de países da Organização do Tratado do Atlântico Norte, OTAN, Carreira apontou para a "importância da masculinidade para os militares" e, por conseguinte, para a "luta pelos direitos dos homossexuais" que emergiu de forma nem sempre silenciosa em instituições conservadoras como as Forças Armadas (CARREIRAS, 2004, p. 68). Para Celso Castro e Maria Celina D’Araujo, a incorporação de "mulheres e homossexuais às Forças Armadas só pode ser devidamente considerada quando as sociedades estabelecem para si que a liberdade de escolha e os direitos iguais para todos são parte inviolável da soberania individual". Para estes autores, a "homossexualidade, em praticamente todas as partes da América Latina, é vista como desvio ou depravação moral, uma doença, uma anomalia ou indignidade social” (CASTRO; D’ARAUJO, 2006, p 39 40)22. O debate sobre a "descriminalização da homossexualidade" nas Forças Armadas na América Latina ainda está em sua fase inicial, mas no ano de 2002, o

Executivo encaminhou projeto de lei ao Congresso Nacional sobre direitos humanos, propondo alterar o artigo 235 do Código Penal Militar de 1969, que prevê punições para práticas "libidinosas", homossexuais ou não, em dependências militares. A proposta é abolir as palavras pederastia e homossexuais (CASTRO; D’ARAÚJO, 2006, p. 39 - 41).

Na chefia do SAREx, Müller recebeu a tarefa de demonstrar que a Igreja Católica não era a única "dona do terreno" na capelania do Exército Brasileiro e que os capelães protestantes eram tão "imperfeitos" quanto os católicos, mas, prioritariamente, para responder ao desgaste dos "chefes militares" em relação à intolerância aos religiosos homossexuais. Porque - de forma inegociável - a "masculinidade" dos militares era sustentada pela moral religiosa cristã, tanto católica, quanto protestante. Por lógico, tratava-se, diante da moral vigente nas Forças Armadas, de um "problema” religioso e institucional grave; pois, entre os religiosos capelães, conforme Alberto da Costa Reis, existiam ministros que não viviam de maneira "casta" e que eram homossexuais adjetivados como “promíscuos”. Em palavras finais, Alberto da Costa Reis concitou Müller a se

\footnotetext{
${ }^{22}$ A incorporação de mulheres nas Forças Armadas do Brasil se iniciou na Marinha em 1980, passando para a Força Aérea Brasileira em
} 1982 e terminou, tardiamente, com o Exército Brasileiro em 1992 (CASTRO; D’ARAUJO, 2006, p 39 - 40). 
preparar para assumir o seu papel e a missão que o esperava, bem como lhe recomendou fidelidade à função de um ministro capelão defensor da "moral religiosa ortodoxa" e da "masculinidade militar": "basta não desertares do combate até o dia em que Cristo te chamar para junto d'Ele”. Depois do diálogo com Alberto da Costa Reis, Müller reconheceu no registro de suas memórias: “para mim foi surpreendente, de escutar palavras de tamanho incentivo e de ânimo para a perseverança no serviço, não só no tempo da ativa, mas também depois, para ser encontrado disponível como Capelão" (MÜLLER, 1999c, p. 6 - JORNADAS NORDESTINAS 5).

A satisfação do colaborador ao atingir a patente mais alta para um capelão do Exército Brasileiro, contudo, não foi tão grande quanto aquela de alcançar a chefia do SAREx. Consciente do ineditismo da ascensão de um acatólico ao comando do SAREx, Müller não hesitou ao dizer: "entrei para a história do Exército Brasileiro". Em sua entrevista, Müller me disse: "eu recebi isso, por um lado, com uma alegria profunda" e, por outro lado, com "humildade". Com forte conotação religiosa, aduziu Müller que: "estava disposto a ir me esvaziando de mim mesmo para continuar aquilo que sempre tinha sido: um administrador fiel para estar atento aos padres e pastores” do Exército Brasileiro. Se em 1964, o colaborador ingressou no serviço militar obrigatório no $17^{\circ}$ Regimento de Infantaria em Cruz Alta, no Rio Grande do Sul, e em 1983 ele foi incorporado na AMAN como oficial do Exército Brasileiro, em 1999 deixou Brasília como coronel reformado convicto de seu "ufanismo", bem como da "moralização", da "conduta disciplinar austera" do SAREx".

\section{Considerações finais}

Em um primeiro momento, analisei as memórias do capelão luterano Müller, a sua "história de vida" religiosa e militar. Desde o serviço militar obrigatório, Müller pretendeu se tornar um capelão protestante, mas isso denotou uma superação de dificuldades em razão da predominância católica romana no 
Exército Brasileiro. De narrativa anticomunista, Müller remontou o golpe civilmilitar de 31 de março de 1964 como “A Redentora”. Com pressupostos ufanistas, Müller considerou que o golpe civil-militar supramencionado foi, ao contrário, uma revolução que "salvou o Brasil” do "comunismo diabólico”.

Abordei, em um segundo momento, a presença de Müller em um conclave da IECLB no qual ele se deparou com quem nominou de "a senhora Xambioá": tratou-se de uma líder leiga luterana que disse ter visto Müller na guerrilha do Araguaia. Com isso, problematizei o "estar" e "não estar” com base nos caminhos, nem sempre precisos, da memória coletiva. Demonstrei como o anticomunismo da Guerra Fria se fez presente no entrave de Müller com uma sobrevivente, de nome não revelado, da guerrilha do Araguaia. As tensões entre os religiosos da IECLB foram demonstradas ainda que por apenas um episódio neste artigo.

Finalmente, apontei para as relações de poder presentes na escolha de Müller como capelão não católico, protestante, para a chefia do SAREx entre 1998 e 1999. Tal escolha apontou para procedimentos morais recrudescidos no âmbito do SAREx, mas sob a aparência de "tolerância", de "tolerância religiosa". Não somente o anticomunismo, as tensões institucionais e as propostas de tolerância religiosa dentro do Exército Brasileiro foram suscitadas, mas também a intolerância ortodoxa e institucional da instituição castrense em relação a alguns capelães católicos que, segundo as memórias de Müller, eram homossexuais. Por isso, a chefia do colaborador no SAREx, entre 1998 e 1999, demonstrou ter sido projetada por diálogos de bastidores que revelaram as referidas relações de poder.

\section{REFERÊNCIAS}

ARQUIDIOCESE MILITAR DO BRASIL. Ordinariado Militar do Brasil. Disponível em: <www.arquidiocesemilitar.org.br/historia >. Acesso em: 26 mar. 2016.

BRASIL. Comissão Nacional da Verdade. Relatório/Comissão Nacional da Verdade. v. 1. Brasília: CNV, 2014a. 976 p. 
BRASIL. Comissão Nacional da Verdade. Relatório/Comissão Nacional da Verdade. v. 2. Brasília: CNV, 2014b. 416 p.

BRASIL. Comissão Nacional da Verdade. Relatório/Comissão Nacional da Verdade. v. 3. Brasília: CNV, 2014c. 1996 p.

BURNS, E. Bradford. Nationalism in Brazil: a historical survey. New York: Frederick A. Prager Publishers, 1968.

CABRAL, Pedro. Xambioá: guerrilha no Araguaia. Rio de Janeiro: Record, 1993.

CARREIRAS, Helena. Diversidade Social nas Forças Armadas: Género e Orientação Sexual em Perspectiva Comparada. Nação e Defesa, Porto, n. 107 - 2 a Série, p. 61 - 88, 2004.

CASTRO, Celso; D’ARAÚJO, Maria Celina. Democracia e Forças Armadas no Brasil da Nova República: balanço de uma pesquisa. In: ABREU, Alzira Alves de (Org). A democratização no Brasil: atores e contextos. Rio de Janeiro: Editora FGV, 2006.

CERTEAU, Michel de. História e psicanálise: entre a ciência e a ficção. Belo Horizonte: Autêntica, 2011.

CHAUI, Marilena. Brasil: mito fundador e sociedade autoritária. São Paulo: Editora Fundação Perseu Abramo, 2001.

CRIVELARI, Ubiratan Nelson. A Importância do profissional “capelão”: força vital na consolidação do Exército Brasileiro. 2008. Dissertação (Mestrado em Ciências da Religião) - Centro de Educação, Filosofia e Teologia, CEFT, Universidade Presbiteriana Mackenzie, São Paulo.

DREIFUSS, René Armand. 1964: a conquista do Estado. Petrópolis: Vozes, 1981.

ESCOLA SUPERIOR DE TEOLOGIA. História. Disponível em: <www.est.edu.br/conheca-a-est/historia. Acesso em: 18 mar. 2016.

EXÉRCITO BRASILEIRO. História do SAREX. Disponível em: <www.portal.dgp.eb.mil.br/portalsarex/sarexdgp.asp>. Acesso em: 15 mar. 2016.

FERRAZ, Francisco César Alves. A guerra que não acabou: a reintegração social dos veteranos da Força Expedicionária Brasileira (1945-2000). 2002. Tese (Doutorado em História Social) - Faculdade de Filosofia, Letras e Ciências Humanas, FFLCH, Universidade de São Paulo, São Paulo.

FOUCAULT, Michel. "L'herméneutique du sujet cours au Collège de France". 1981 - 1982. édition publiée sur la direction de François Ewald e autres. Paris. Gallimard, 2001.

FOUCAULT, Michel. Microfísica do poder. São Paulo: Editora Graal, 1994. 
GASPARI, Elio. A Ditadura Escancarada, as Ilusões Armadas. São Paulo:

Companhia das Letras, 2002.

GORENDER, Jacob. Combate nas Trevas. São Paulo: Ática, 1987.

HALBWACHS, M. A memória coletiva. São Paulo: Vértice, 1994.

HERVIEU-LÉGER, Danièle; WILLAIME, Jean-Paul. Sociologia e religião. Aparecida: Idéias \& Letras, 2009.

LE GOFF, Jacques. História e memória. Campinas: Editora da UNICAMP, 2003.

LE GOFF, Jacques; NORA, Pierre (Org.). História: novas abordagens. Rio de Janeiro: Livraria Francisco Alves Editora, 1976.

MEIHY, José Carlos Sebe Bom; HOLANDA, Fabíola. História Oral, como fazer, como pensar. São Paulo: Editora Contexto, 2013.

MEIHY, José Carlos Sebe Bom; RIBEIRO, Suzana Lopes Salgado. Guia prático de história oral: para empresas, universidades, comunidades, famílias. São Paulo:

Contexto, 2011.

MENDONÇA, Antonio G.; VELASQUES FILHO, Prócoro. Introdução ao

Protestantismo no Brasil. São Paulo, Loyola, 2002.

MONTENEGRO, Antonio. História oral, caminhos e descaminhos. Revista Brasileira de História, São Paulo, n. 25/26, p. 55 - 65, 1993.

MORAES, Dênis de. A Esquerda e o Golpe de 64. São Paulo: Expressão Popular, 2011.

MORAIS, Tais de; SILVA, Eumano. Operação Araguaia: os arquivos secretos da guerrilha. São Paulo: Geração Editorial, 2005.

MOTTA, Rodrigo Patto Sá. Em guarda contra o "Perigo Vermelho": o anticomunismo no Brasil (1917- 1964). São Paulo: Perspectiva: FAPESP, 2002.

MÚLLER, Elio Eugênio. JORNADAS NORDESTINAS 1. SAREX/ARQUIVO DO AUTOR, 1999a.

MÚLLER, Elio Eugênio. JORNADAS NORDESTINAS 2. SAREX/ARQUIVO DO AUTOR, 1999b.

MÚLLER, Elio Eugênio. JORNADAS NORDESTINAS 5. SAREX/ARQUIVO DO AUTOR, 1999c.

NAPOLITANO, Marcos. 1964: História do Regime Militar Brasileiro. São Paulo: Editora Contexto, 2014. 
NOSSA, Leonêncio. Mata! O Major Curió e as guerrilhas no Araguaia. São Paulo: Companhia das Letras, 2012.

PAPA PAULO VI. Decreto Unitatis Redintegratio - sobre o ecumenismo, Vaticano, 21 nov. 1964. Disponível em:

<www.vatican.va/archive/hist_councils/ii_vatican_council/documents/vatii_decree_19641121_unitatis-redintegratio_po.html>. Acesso em: 14 dez. 2016.

PEIXOTO, Rodrigo Corrêa Diniz. Memória social da Guerrilha do Araguaia e da guerra que veio depois. Boletim do Museu Paraense Emílio Goeldi - Ciências Humanas, Belém, v. 6, n. 3, p. 479-499, 2011.

PESSOA, Romualdo Campo Filho. Guerrilha do Araguaia: a esquerda em armas. Goiânia: Editora UFG, 1997.

POLLAK, Michael. Memória, esquecimento, silêncio. Trad. Dora Rocha Flasksman. Rio de Janeiro: Estudos Históricos, 1989.

PORTELA, Fernando. Guerra de Guerrilha no Brasil: A Saga do Araguaia, Nova entrevista de José Genoino. São Paulo: Editora Terceiro Nome, 2002.

PORTELLI, Alessandro. A filosofia e os fatos. Tempo, Rio de Janeiro, v. 1, n. 2, 1996.

SALES, Jean Rodrigues. Partido Comunista do Brasil: definições ideológicas e trajetória política. In: RIDENTI, Marcelo; AARÃO REIS, Daniel (Orgs). História do Marxismo no Brasil. Campinas: Editora da Unicamp, 2007.

SCHÜNEMANN, Rolf. Do Gueto à Participação: o Surgimento da Consciência SócioPolítica na IECLB entre 1960 e 1975. São Leopoldo: Sinodal/IEPG, 1992.

SEAWRIGHT, Leandro A. Ritos da oralidade: a tradição messiânica de protestantes no Regime Militar Brasileiro. 2016. Tese (Doutorado em História Social) - Faculdade de Filosofia, Letras e Ciências Humanas, FFLCH, Universidade de São Paulo, São Paulo.

SILVA, Elizete. Conflitos no campo religioso baiano: protestantes e católicos no século XII. Sitientibus, Feira de Santana, n. 21, p. 51 - 67, 1999.

STUDART, Hugo. A Lei da Selva: estratégias, imaginário e discurso dos militares na Guerrilha do Araguaia. São Paulo: Geração, 2006.

THOMPSON, Paul. A Voz do Passado História Oral. São Paulo: Paz e Terra, 1992. 